\title{
肥前名護屋城の石垣における「城割」の実態と意味 "SIRO-WARI" SYSTEM ON THE STONE WALLS OF HIZEN NAGOYA CASTLE
}

\author{
木島孝之* \\ Takashi KIJIMA
}

\begin{abstract}
I hope my thesis will provide a key to the progress in the study of "Shiro-wari" system. To begin with, I've taken the case of Hizen Nagoya Castle and given an example of removal of stone walls in terms of the superficial observation. l've considered how castles were influenced under "Shiro-wari" system through the analysis of the case of Hizen Nagoya Castle. From my study so far l've come to the conclusion as follows:

1) Judging from the present appearance of the stone walls of Hizen Nagoya Castle, they seemed to be fallen down artificially, which l've proved by giving a convincing example in this thesis. 2) "Shiro-wari" was a ritually-colored system to have castles suspend their functions temporally, but never to make them lose their functions completely.
\end{abstract}

Keywords:"Shiro-wari", Hizen Nagoya Castle, castle, stone walls, ”城割”, 肥前名護屋城, 城郭, 石垣

1.はじめに

近年の城郭研究は考古学、文献史学、歴史地理学等の 分野を越えた学際的な研究のもとで飛躍的に発展しつつ ある。その中で注目されるのが「縄張り研究」と称され る新たな研究分野である。この研究は城郭遗構の表面観 察により解䣋した城郭の「縄張り」（註 1 ）を「縄張り 図」（註 2）に作成し、この図面をもとに城郭の“かた ち”（堀・土塁・虎口の形状 (プラン)、曲輪の配置や形状 等）を分析し、それを創出した権力や社会の様相を考察 しようとするものである。この研究の利点は、遗構の破 壊を伴うことなく城郭の最終期の姿を知ることができ、 また、調查は多大な労力や経費を必要とせず手軽に行え るということにある。この利点から近年、「縄張り研究」 が各地で盛んになり多くの「縄張り図」が研究成果とし て提示されつつある。

ただ、「縄張り」を解釈する場合に、「縄張り研究」 を行う者なら恐らく誰もが経験したであろう問題、つま
り現在破損している遺構が人為的な破却を経たものか否 か、すなわち「城割」（註 3）かどうかという問題が今 までそれほど注目されずにきた嫌いがある。実際、城郭 の「縄張り」調查を続けていると崩壊した石垣をたびた び目にするが、その城郭に元和「城割」令等による「城 割」の記録・伝承等が残る場合、崩壊している石垣遺構 を即座に「城割」と結びつけたくなり、自然崩壊という ごく当たり前のことをつい忘れがちになってしまう。安 易に石垣の崩壊と「城割」の記録を対応させることは、

「城割」という行為の意義を見えなくしてしまう恐れが ある。なぜなら、「城割」の記録の残る城郭遗構をみた 場合、石垣を崩すもの（鷹取城（註4））がある一方で、 崩さないもの（獅子ヶ城（註 5)）もあり、この一律で ない実態には何らかの政治的・社会的要因が反映されて いることが予測されるからである。ここで、石垣がどう いう崩れ方をしている場合が人為的な破却なのかを見分 ける方法が必要となってくる。

* 九州大学工学部建築学科 大学院生·工修

Graduate Student, Dept. of Architecture, Faculty of Engineering, Kyushu Univ., M. Eng. 
考古学の分野では、発掘により黒田領の鷹取城（文献 4) と伊達領の木村館（文献 5 ）の石垣の破却が確認さ れた例がある。これらの事例では、崩落した石材の間に 堆積した土砂の状態から人為的な破却であったことが検 証されている。一方、地表面観察を主とする「縄張り研 究」の分野では、今のところ破却を受けた石垣の明確な 実例は提示されていない（註6）。破却を検証するには 発掘が最も有効な手段といえるが、ただ発掘を行うにし てもまず破却か否かの予測を事前につけておくことは大 変重要なことである。なぜなら、予測なしに発掘を行っ てしまった場合、崩壊した土砂や石材を作業に邪魔なも のとして安易に撤去し、破却か否かを沓久に判らなくし てしまう恐れがあるからである。また、発掘による検証 にはかなりの時間と莫大な経費がかかり、この方法のみ では城郭の資料化がなかなか進まないという現状がある。 そのため、まずは地表面観察による「縄張り研究」で予 測をつけ、次いで考古学的にそれを検証していくという 手順が城郭研究の望ましい方法であると考える。そこで 地表面観察による「縄張り研究」の立場から「城割」に よる人為的な破却を検証する方法が必要になっている。

次いで「城割」か否かの問題に絡んで、近年、考古学 の発掘成果を基に「城割」の意味について再検討を促す 見解が出され注目されている。一般に、「城割」という 言葉が与えるイメージは城の戦闘機能を消滅させる程の 徹底的な破却であろう。しかし、部分発掘された南部領 の根城（文献 7 ) 、伊達領の木村館 (文献 5 ) の調查結 果では、城跡を土塊にしてしまうような徹底した破却は 行われておらず、主要な部分を限定的に崩すものであっ たことが報告されている。具体的には、木村館の場合、 外郭部の桝形虎口の石垣が徹底的に破却されているのに 対して、城域全体に設けられた土畦・空堀等の遗構はほ ぼ完全な状態で残っている。伊藤正義氏はこの実態を受 けて、「外からよく見える出入口施設＝虎口は徹底的に 破壊されている。しかし、外からよく見えない部分の土 畕などは、かなり元の姿を留めている。やはり伊達領で も、城破りは、徹底した破壊・廃城というよりも、あた かも坊主頭になって恭順の意を表すのに似た、秀吉への 服従を表す象徵的な行為だったにちがいない。」（文献 8）という、「城割」は儀礼的な要素が強いという主旨 の見解を述べておられる。ここで虎口を城の顔に当たる 部分と捉えれば、それを壊すという点で確かに儀礼的要 素が強いという解釈が可能である。しかし、虎口が城内 で最も重要な場所であり（防御の上で最大の弱点となる

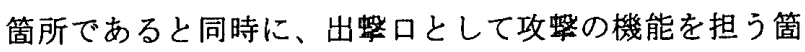
所である）、しかも木村館の破却された虎口は出撃性の 強い外枡形虎口（註 7) であることを考えた場合、この 虎口の破却は戦闘機能を奪う上で最も有効であると考え られる。したがって、木村館は「城割」の儀礼的側面と
いうより、むしろ実質的側面を物語る事例とすべきでは ないかと思われる。しかし発掘調查による事例の提出に 伴って「城割」における儀礼的要素に関する研究が、今 後ますます注目されることは確実であろうと思われる。 それに際して地表面観察による「縄張り研究」の見地か らもこの問題に関する事例を提示し、議論に参加して行 くことが必要であろうと思われる。

上述の問題意識から本稿ではまず、肥前名護屋城の遺 構の現地調查によって作製した「縄張り図」を用いて、 石垣の破却を検証する方法の一例を提示する。そしてこ の石垣の破却の形態の中で「城割」における儀礼的要素 とは何かを検討し、「城割」に対する理解を深めること を目指す。

\section{2. 文献史料にみられる肥前名護屋城の「城割」}

肥前名護屋城は天正 19 年 (1591)、朝鮮出兵の際の本 営として豊臣政権によって築かれた大城郭である。その 石垣は高さ $4 \sim 11 \mathrm{~m}$ 、延長 $2000 \mathrm{~m}$ にも及ぶ大規模 なもので、所々に崩壊がみられるもののほぼ完全な形で 現存している。

肥前名護屋城の「城割」に関する同時代史料は今のと ころ見い出せない。後世の記録では以下のものが挙げら れる(註 8)。

『松浦記集成』（第一編 松浦黨並古城）一「六 唐 津城 寺澤家興廢の次第 寺澤志摩守唐津城を築かれし 事、其起元文祿元壬辰年秀吉公朝鮮征伐、同三甲午春諸 侯歸陣の時、岸获城主波多三河守朝鮮國釜山より歸帆、 直に常陸國筑波山の麓に配流の下知有る之、右同二月九 日也。其波多領八萬三千二十九石七升寺澤家一被下、岸 獄城一圓拜領となる。田中の城に當時假城とし、其後名 護屋城も領内の中にて、不用の城廓櫓門、屏、等拜領に て是を毁ち取り、唐津に城地を見立船送して築かるる」

(註 9)

『松浦記集成』（第六編 古事）一「一 唐津城 天 正十九年辛卯、秀吉公朝鮮之役、名護屋御在陣、文祿三 甲午諸將歸朝となる、同二月九日波多三河守鎮公流罪と なる、依之蕃領松浦郡、草野領怡土・松浦、都合八萬三 千石志州公唐津拜領、後ち天草四萬石を合せ十二萬三千 石となる。志州公、初は田中島村城に居られ、郷中所々 新田御普請に及び、元和二丙辰年波多、草野舊領再檢地 等有之、唐津城御普請、名護屋城並御陣所の材木拜領に て成就有之候、」（註9）

『松浦昔鏡』（唐津城の根源）一「都合十二萬三千石 寺澤志摩守殿御拜領被成、初て田中に御入城被成、夫よ り文祿年中唐津城取立、名古屋御城の御材木にて御普請、 今之唐津御城是なり。」（註10） 
『松浦要略記』（唐津城主御代々）-「一唐津御城 御普請 慶長七壬丑年より始まり同十二年迄七ヶ年にて 御成就有是候。名護屋御城の道具・材木不殘御引取被成 候」（註11）

『松浦拾風土記』（巻二）-「四十三 寺澤志摩守殿 之事並鏡宮神整寺澤兵庫頭殿變死之事 唐津八萬三千石、 天草四萬石都合十二萬三千石拜領有り、名護屋の御城を 引き、唐津に築城、」（註12）

『唐津拾風土記抄』一「垣副城 名古屋肥前守藤原經 元よりー（中略）一越前守經延迄十代の居城なり、然る 處天正十九年豊公朝鮮征伐陣城御築の節、當城差上、經 延は殿前に引移り、其跡今殘る御城也、凱陣の頃諸營石 垣等まで引け、今の唐津御城是也、名古屋城破却せられ けれども廣大なる事ゆへ今なほ存せり、垣副の城は消失 たり、今天守套の所なるべし。」（註13）

『広澤寺文書』一「寺澤志摩守様名護屋御城御拜領慶 長四已亥年より享保二年迄百二十年程然共名護屋御城に は不被成御座唐津御城御普請被成御屋形御引取御立被成 侯由申傳候御父子樣御代四十七年程云々」（註14）

さて、ここに挙げた史料から肥前名護屋城の「城割」 に関してどのようなことが判るであろうか。

まず、肥前名護屋城の「城割」の時期についてである が、寺澤氏の唐津築城に際して行われたという点ではど の史料も共通している。ただ唐津城の築城の年代につい ては、『松浦昔鏡』は文禄年中 $(1592 \sim 1594)$ とし、『松 浦要略記』は慶長 7 年 (1602) よりとし、『唐津拾風土記 抄』は朝鮮役からの凱陣の頃（慶長 3 年 (1598)）、とし ている。そしてその他の史料では、具体的な年代は記さ れていない。

次いで破却の内容についてであるが、史料によって微 妙に表現が異なる。つまり、『松浦記集成』（第六編古 事）・『松浦昔鏡』には「材木」が唐津城に転用された こと、『松浦要略記』には道具・材木が残らず唐津城に 引き取られたこと、『松浦記集成』（第一編 松浦黨並 古城）には櫓門、塀等が壊され唐津城に船送し転用され たこと、『松浦拾風土記』には肥前名護屋城の何らかの ものが唐津城に引かれたこと、『広澤寺文書』には「御 屋形」が唐津城に引き取られ建てられたこと、が記され ている。また、『唐津拾風土記抄』には諸侯の陣所（肥 前名護屋城の周囲に百箇所以上の諸大名の陣城がある) が「石垣等まで」唐津城に引かれたことが記されている が、肥前名護屋城自身については破却されたとあるもの の具体的な内容は記されていない。

これらの史料の記載から、肥前名護屋城は寺澤氏の唐 津築城に際して、何らかの形で「城割」を受けたという ことが判る。しかし、破却の内容に関する記述が史料に より微妙に異なるため、破却がどの程度のものだったの
かについては、はっきりしない。そして、所々にみられ る石垣の崩壊がこの時の「城割」によるものかどうかに ついては全くわからない。

その後については、幕府から出された元和の「城割」 令による破却の可能性が考えられるが、それに関しての 記録はない。また、寛氷 14 年 (1637)、天草乱の残党軍が この城に立篭もるという風説があり、驚いた唐津藩が石 垣の要所を破却したという伝承が残っているようである が、典拠等が示されず詳細は分からない（註15）。なお、 元和の「城割」令に続いて、天草乱の直後に寛永の「城 割」令とでも呼ぶべきものが幕府より出されたのではな いかとの推測を可能にする幾つもの史料がある（註16）。 また、寛永の「城割」令による破却の具体的な事例とし て、1994 年に発掘調查された毛利領の岩国城が挙げ られる（文献18）。この発掘調查によって、天守台に関 しては、元和の「城割」で建築物が破却され、次いで寛 永の「城割」によって石垣が破却されたことが確認され た（註17）。ただ、岩国城の例にしても、元和の「城割」 令による石垣の破却が文献に見え（註18），天守台以外 では寛永の破却がどの程度のものであったかは現段階で は速断できない。元和・寛永の史料、発掘資料を共に久 く肥前名護屋城ではなおさらである。

以上、文献史料から肥前名護屋城の石垣の崩填時期を 推定することは困難といえる。

\section{3.肥前名潇屋城の石垣の崩填状況}

現在、肥前名護屋城の石坦には所々に崩壊した箇所が 見られる。この崩壊の状態を調查し図面化した結果が図 1 「肥前名護屋城䋥張り図」である。これは『特別史跡 名護屋城跡並び陣跡 3 文禄・慶長の役城跡図集』（文 献19）所收の実測図（1/1000）を参考に、筆者が 198 8 年. 5 月と 1994 年 5 月に方位磁石と巻尺および歩測 によって表面観察から作成したものである。そしてこの 図からは石垣の崩壊状況の特徵として、以下の 5 点が举 げられる。

a) 本丸の南面および西面、馬場の南面、遊撃丸の北面は、 畦線をほほ等分するような間隔で崩れている\{あ一い 一う，えーお一かーき，くーけーこ一さ，たーちーつ 一て，とーなーに）（写真 $1 、 2 、 3 、 4 、 5) 。 そ$ の中で本丸の南面と馬場の南面の崩壊箇所は、ほぼ対 応する $\{\mathrm{A} \sim \mathrm{E}\}$ 。また、二ノ丸、東出丸（仮称）、 弹正丸についても畦線をほぼ二分、三分するような形 で崩れている\{せーそ，まーみ，へーほ，し一す，の 一は，ひーふ，ぬ一㸚\}。なお、崩落した石垣は下に 堆積し残存している。また、崩壊箇所周辺の石垣は、 はらみも特にはなく自然崩壊する状態にはない。 

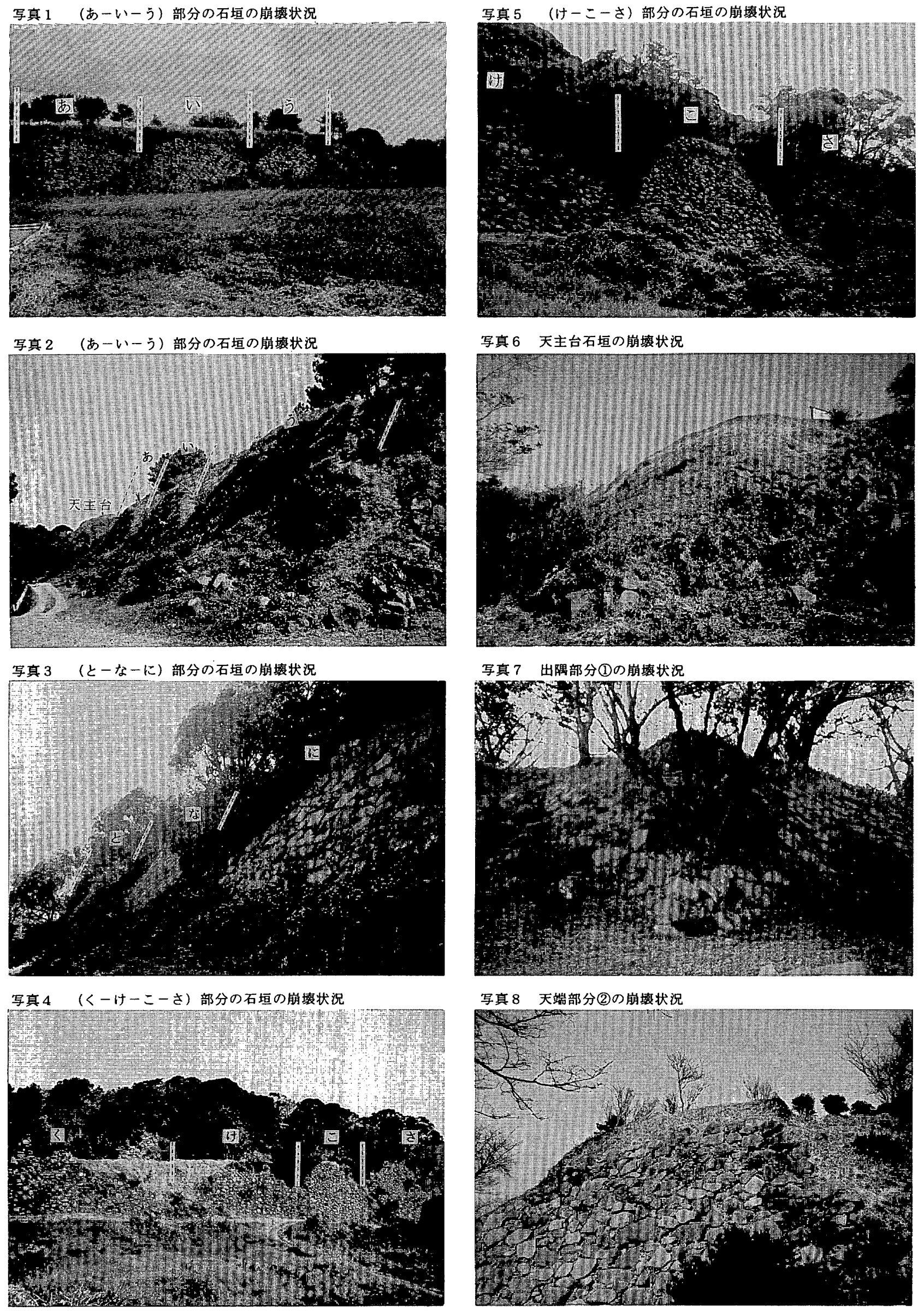


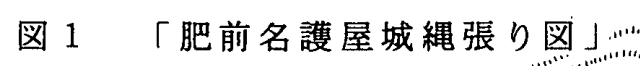

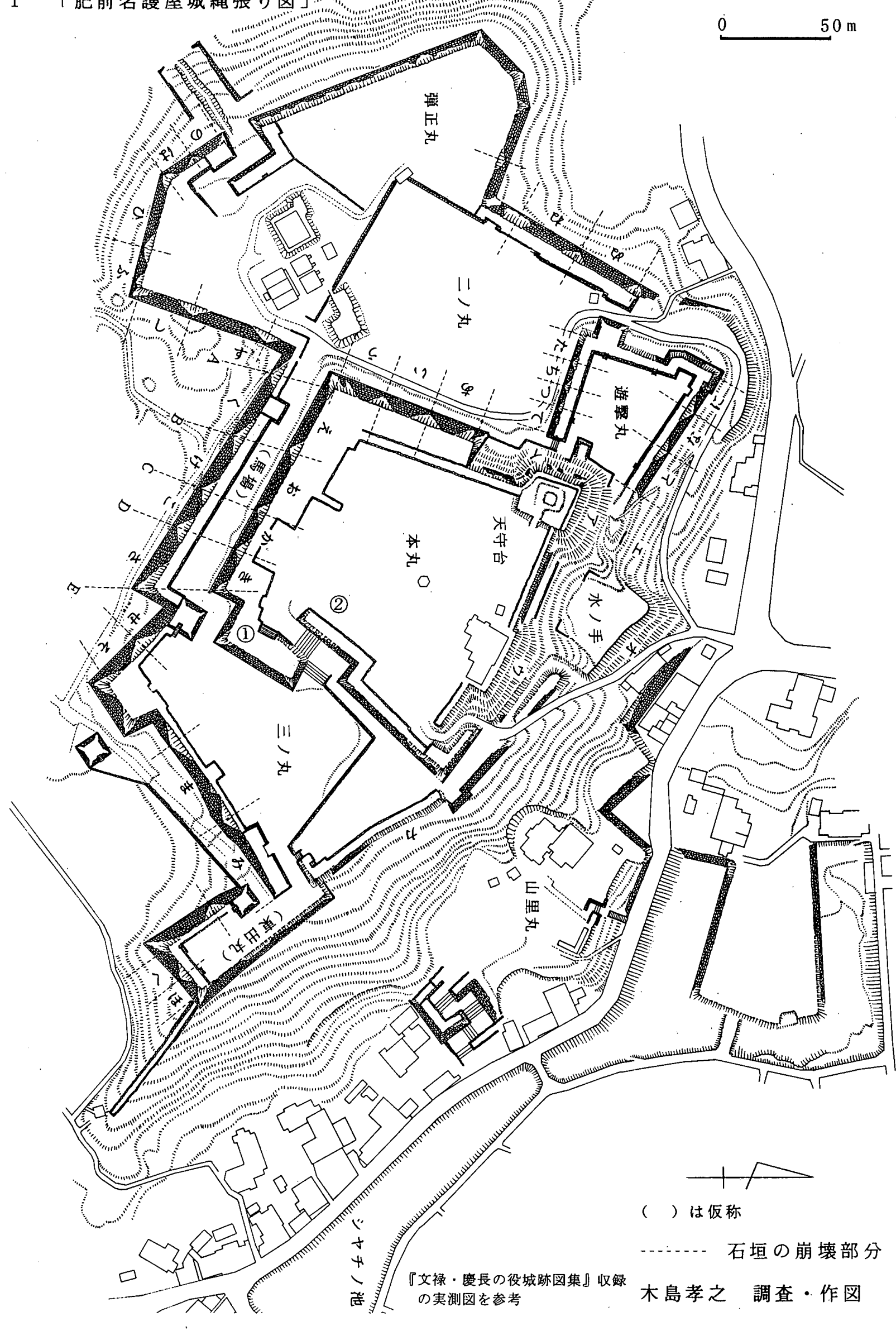


b) 天守台の石垣が完全に崩壊し、崩落した石材はほとん ど撤去されている（写真 6 ）。

c) 水ノ手、本丸の北面、三ノ丸北面の石垣が完全に崩壊

し、崩落した石材はほとんど撤去されている $\{ア 〜 カ\} 。$

d) 数箇所を除き出隅部分の石垣はほぼ根元近くまで崩壊 している(写真 7)。

e) 大半の箇所で天端部分の石垣はほとんど崩壊している (写真 8)。

\section{4. 肥前名護屋城の石垣における破却の可能性について の考察}

前記の崩壊状態の諸特徵から破却の可能性について検 討を加えてみよう。

まず、特徵a)についてであるが、崩壊箇所がピンポイ ント的で、しかもそれがおよその規則性を持っているこ と、そして特にA〜Eの崩壊箇所がほぼ対応しているこ とは、自然崩壊とするには疑問が残る。更に崩壊箇所の 周辺の石垣が健在であることを勘案するといっそう不自 然な観が増す。この特徽a)は破却と考えてまず間違いな いと思われる。

次いで特徴b）、c)についてである。肥前名護屋城の大 部分においては、石垣は完全には崩壊しておらず、また 崩落した石材は下に堆積し残存している。しかし、この 部分の石垣だけが完全に崩壊し、崩落した石材が撤去さ れている状態はやはり不自然である。石材の撤去に関し ては、後世に地元住民によって持ち去られた可能性も考 えねばならないが、集落に近くしかも運搬が容易な城山 の麓にある山里曲輪の石垣がほほ残存することを考えた 場合、丘の上にあり運搬が不便な天守台および本丸北面 ・水ノ手の石材が後世に持ち去られたとは考えにくい。 これは破却と考えるのが妥当と思われる。

次いで特徵d)、e)の考察に移る。一般に天端および出 隅部分の石垣は自然崩壊しやすいものと思われる。この ことから、天端および出隅部分の石垣の崩壊が破却の結 果か否かを判断する際には慎重になるべきである。ただ、 肥前名護屋城の場合、周辺の石垣ははらみがなく健在で あるにも関わらず、出隅部分の石垣のみがほぼ全箇所に おいて根元近くまで崩壊している状態は、やはり人為的 なものであったことを予測させる。この場合、出隅部分 の石垣の破却は、隅櫓の構築を不可能なものとし、更に 石垣を登る際に最も取り付きやすい足場を造る狙いがあ つたと考えられよう。なお、特徵e)の天端の崩壊につい ては破却か否かの判断を下しにくい。ただ他の部分の石 垣の崩壊が破却であることが明らかになったならば、天 端部分の崩壊も破却であった可能性を想定して良いと思 われる。その場合、天端の破却は櫓や土塀等の重量構造 物を㬅線いっぱいに構築することを不可能にするための
措置と考えられよう。

以上、遺構の表面観察の見地から、肥前名護屋城にお いて現在観察できる石垣の崩壊について「城割」の可能 性を検討してみた。その結果、要所要所におけるピンポ イント的な崩壊、天守台および本丸北面・水ノ手周辺で の完全な崩壊と石材の撤去、出隅部分におけるほぼ全简 所での崩壊など、極めて特殊な崩壊があることが指摘で きた。そしてこの実態から、肥前名護屋城にみられる石 垣の崩壊は全て人為的な破却の結果であった可能性が強 いことを提示した。

\section{5. 肥前名讙屋城の「城割」における儀礼的側面の検璟} 前章に执いて肥前名護屋城の現在の石垣には「城割」 による人為的な破却を受けた形跡があると判断したわけ であるが、それではその破却の形態の中に「城割」の儀 礼的要素を認めるべきであろうか、あるいは戦闘機能の 剥奪という実質的要素の方を強く認めるべきであろうか。 ここでは、ピンポイント的な破却の形状に注目してみ たい。これに関しては、肥前名護屋城の膨大な石垣を大 々的に崩すのに要する労力的・経済的負担を考えるとや むをえない措置だったとの解釈もできよう。ただ、「城 割」の第一の目的が戦闘機能を剥奪することにあるなら ば、破却の労力をピンポイント的に散らせるのではなく、 城内で最も重要な箇所である虎口部分に集中させその形 状さえ崩してしまう程の破却を加えたほうが戦闘機能に 与えるダメージは絶大である。織豊系城郭の場合、特に 虎口のプランには最大の努力が注がれ、他の戦国大名の 城郭における虎口のプラン（形状）と比べて格段の発展 を遂げてきた経緯がある（文献 9 ）。肥前名護屋城にお ける本丸東側の虎口は外桝形（註19）と呼ばれるとりわ け攻慗性の強い虎ロプランであるが、これは織豊系城郭 の「縄張り」の発展過程において根幹的な役割を果たし たプランである（文献 9 ）。また東出丸（仮称）のプラ ンは、外桝形虎口の出转性をさらに高めるために勢溜と なる虎口空間を拡大させ橋頭堡的機能を持たせた非常に 攻撃的なプランである。同様のプランが近江八幡城・石 垣山城等の豊臣政権の代表的な城郭の大手口にも使われ ている。このように肥前名護屋城における虎口は内栘形 ・外桝形という織豊系城郭の軍事技術の粋を集め計画さ れたプランである。しかし肥前名護屋城の虎口部には、 他の箅所と比べた場合、特に入念に破却された痕跡はな い。それどころか、木村館における虎口の徹底的した破 却とは対照的に、肥前名護屋城の虎口は現在でも形状は 明確であり、積極的な破却の意図は認められないという べきである。このことから、肥前名護屋城の石垣におけ るピンポイント的な破却が、（経済的・労力的制約を考 慮したとしても）戦闘機能の消滅、つまり“城を使えな 


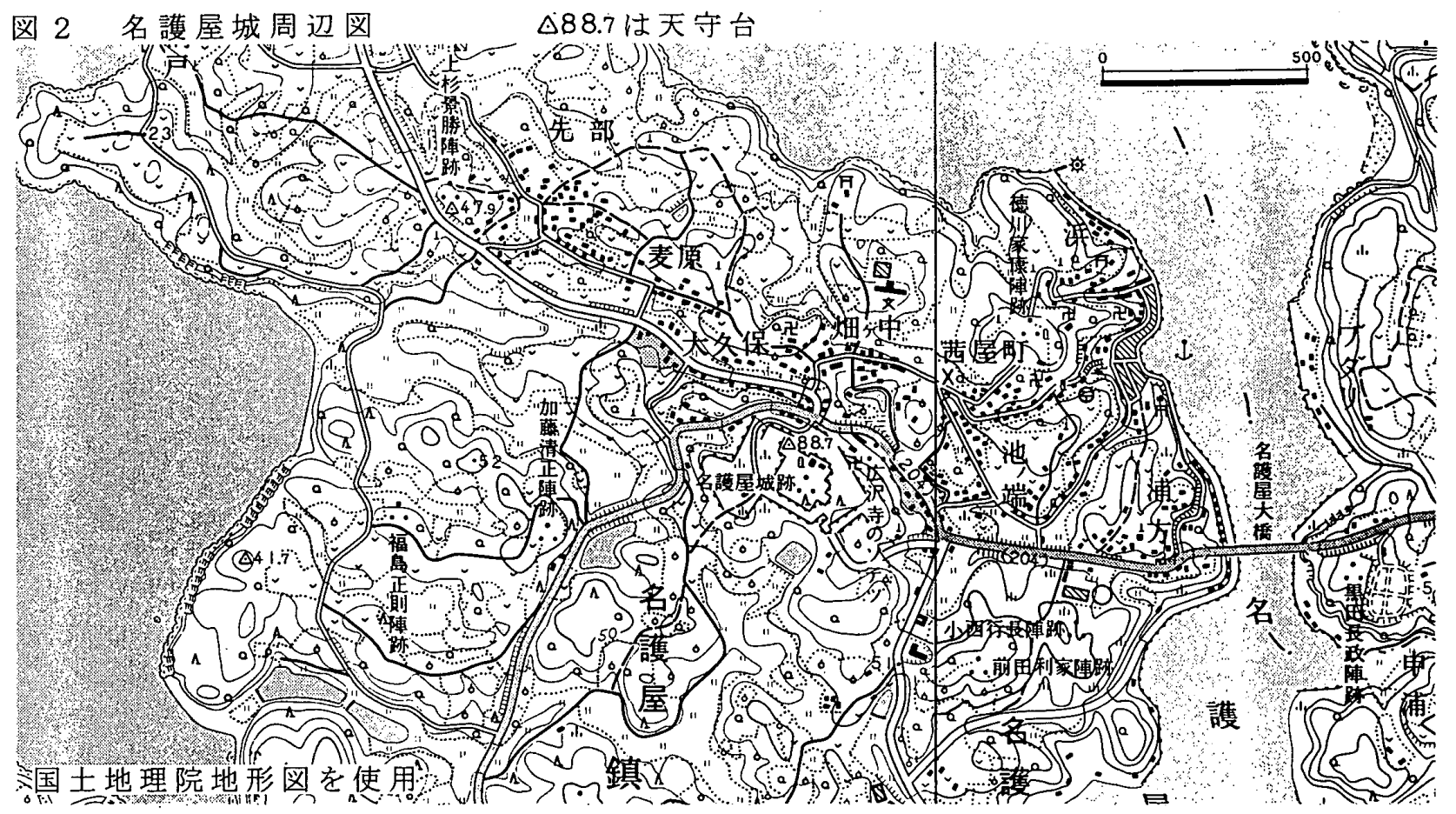

くする”ことを第一の目的にしたものだったとは考えに $<\omega_{0}$

むしろ、ピンポイント的な破却の場合、城の疁線をほ ぼ等分するような間隔で満遍なく破断が入ることが重要 であろう。この手法ならば城外のどの場所から見渡して も破却行為が行なわれたことが確認できるからである。

そしてこれは、城郭の戦䦢機能を温存しつつ、少ない破 却の労力で “城を使わない”という意志を出来るだけ表 明しようとする意図と解釈すべきではないだろうか。ま た、延々と延びる眰線をほぼ等分するような間隔で破断 が入れられていることに加え、馬場の南面と本丸の南面 の破断箇所 $(\mathrm{A} \sim \mathrm{E})$ がほぼ対応している形態は、形式 性を帯びており“みせる”ことを強く意識した儀式的な ものと解釈す心゙きではないだろうか。以上のことから、 ピンポイント的な破却の形態の中に城郭の機能（戦闘要 塞、威嚇、権力の象徽）の一時的な停止・凍結の意志表 明を目的とした儀礼的要素を汲み取ってよいのではない だろうか。

次いで天守台および本丸北面・水ノ手の石垣が徹底的 に破壊されたうえに石材まで撤去されている状態に注目 してみたい。

肥前名護屋城の立地をみると（図 2)、城の南・西・ 東方面には丘陵地が続く。北側方面にのみ、谷間部分を 利用した集落が形成されている。大久保、麦原、畑中、 池ノ端、茜屋町、浜の辺りである。「名護屋城並諸侯陣 跡之図」(文献20所載）には朝鮮役当時の城下町之思わ れる

「ムキハラ丁」、「大久保丁」、「ナコヤ丁」、「材木 町」、「アカネヤ丁」、兵庫町」、「古里町」等の集
落が描かれており、現在の地名と対照すれば、大久保が 「大久保丁」、麦原が「ムキハラ丁」、池之畑が「材木 町」・「ナコヤ丁」、茜屋町が「アカネヤ丁」・「兵庫 町」、浜が「古里町」に比定できる。朝鮮役の終了後、 これらの城下町はその機能を終え江戸期には名護屋村と して一般集落化したものと考えられるが、村高は「慶長 肥前国絵図」（註20）に2843石余、「正保肥前国絵図」 （註21）に1995石余とあることから、かなり大きな村と して残ったものと推定される。

この集落（旧城下町）汃ら肥前名護屋城を眺めた場合、 城の北面が視覚の対象となる。城の北面は前述のとおり、 他の方面と比べて大々的に破却されている。戦闘力を削 ぐ目的からは、北面が他の方面よりも特に重要であると いうわけではない。したがって、この現象からは、破却 行為を積極的に人目に触れさせようとする意図が伺え、 ここに「城割」の儀礼的な要素を汲み取ってよいのでは ないだろうか。また、山上の天守は集落（旧城下町）か らはひときわ目立つ位置に配直されているが、これは高 々とした天守台の石垣と高層の楼閣建築を人々に見せつ けることで、権力の絶大さ（財力、動員力、威圧感等） を誇示する狙いがあったものと考えられる。したがって、 城中で最も権力の象徵としての機能を帯びた天守が石垣 までも徹底的に破却されている状態は、城郭が持つ機能 の中でも特に権力の象徴・威嚇という部分を停止・凍結 したことを視覚的に表明するための儀礼的措置と解釈で きるのではないだろうか。

\section{6. 肥前名護屋城の石垣の破却の目的と時期の検討}


文献史料の面からは肥前名護屋城の石垣の破却時期に ついて三つの可能性、つまり、慶長の唐津築城時、元和 の「城割」時、天草乱直後の寛永の「城割」時を挙げる ことができるが、石垣の破却の目的と時期を特定するこ とは不可能であった。それでは、遺構の面より石垣の破 却の目的と時期を特定することはできるであろうか。こ こでは肥前名護屋城の石垣の破却方法が戦闘機能を剥奪 することに主眼を置くものではなく、“城を使わない” という意志を儀礼的に表明するものである、つまり天守 という象徵的な部分や集落から見える方面を大きく破却 したり、畦線を等分化するような形式性を帯びた破却形 態を採っていることに注目してみたい。

“城を使わない”という意志を儀礼的に表明するため に石垣を破却する場合、誰が誰に対して儀礼を尽くす必 要があるのかということが問題となろう。この際、二つ の場合が考えられよう。まず一つは、幕府が大名から余 分な城 (戦闘施設) を取り上げ大名間抗争 (私闘) の凍 結を宣言し視覚化するという目的に対応して、大名が幕 府に対して破却の意を儀礼的に示すということが考えら れよう。そしてもう一つは、大名当主が城持ちの大身家 臣から城主という自律した地位を剥奪する目的に対応し て、城持ちの大身家臣が大名当主に対して持ち城の破却 の意を儀礼的に示すということが考えられよう。これに 関しては、『別本吉川家譜』「廣正公ヨリ御本家一差出 サル、御書物」（文献 3 収録）にみえる毛利領の岩国城 の破却の例が挙げられる。この家譜の記述からは、毛利 輝元が元和の「城割」令を逆手にとって吉川氏（毛利家 中における筆頭重臣）の岩国城を積極的に破却しようと 画策し（註22）、これに対応して吉川氏がとりわけ城の 表の方の石垣を山下からも城からもよく見えるように崩 した（註18）ことが伺える。

肥前名護屋城の場合は、大身家臣の持ち城ではなく、 寺澤氏の直轄であったと考えられる（註23）。したがっ て、肥前名護屋城の石垣にみられる儀礼的な破却の主体 は寺澤氏であったと考えてよかろう。その場合、儀礼を 尽くす相手は幕府ということになろう。目に付きやすい 方面の石垣を集中的に破却することは、寺澤氏が幕府に 対して私戦の凍結の意を表明するために行ったものとみ るのが妥当と考える。これによって虎口部分の破却を免 れるメリットも考えられよう。この見解に立てば、石垣 の破却の時期が慶長の唐津築城時である可能性は低い。 な゙ぜなら、慶長の段階では寺澤氏が儀礼的な石垣の破却 を幕府に示さなければならない必要性は特に見当たらな いのである。また、唐津築城時の「城割」に関する文献 史料には建築物類の破却が記されながら、より多くの労 力を必要とするはずの石垣の破却についての記述がみら れないは不自然である。これは唐津築城時の「城割」が 石垣の破却を伴うものではなかったことを傍証している
のではないかと思われる。

次に石垣の破却の時期について残るのは元和の「城割」 令あるいは寛永の「城割」令による可能性であるが、こ の何れであったのかは率直に言って現段階で特定するこ とは困難である。そのため今後の課題として、寛永の 「城割」と考える場合の問題点について若干ふれてみる ことにする。

まず、寛永の「城割」令に関して、この「城割」令の 性格が『蜂須賀家記』、『越登賀三州志』、『肥後宇土 軍記』および『名護屋城秘史』の風説等が伝えるように、 本当に天草乱のような反乱の再発を恐れての軍事施設の 破却を目的としたものであったならば、虎口部分にこそ 破却のエネルギーを集中させるべきであったろう。そこ でまずは、肥前名護屋城の石垣の破却は寛永の「城割」 令によるものではなかったという解釈が成り立とう。し かし逆に、肥前名護屋城の石垣が本当に寛氷の「城割」 令を受けていたとするならば、この「城割」令の性格は 反乱を恐れてのものではなく、もっと別の真意、つまり 大名の私戦の凍結意志表示を幕府が儀礼的に求めたもの であった可能性を検討する必要が生じてこよう。

\section{7.まとめ}

上記の考察により肥前名護屋城における石垣の崩壊は 「城割」によるものであるとの見解を提示した。その際、 石垣の破却の検証方法の一例が表面観察を主とする「縄 張り研究」の立場から提示できたのではないかと考える。 次いで、肥前名護屋城の石垣の破却におけるピンポイン 卜的な破却と天守台および集落側の徹底した破却の形態 は、戦闘機能を剥奪し“城を使えなくする”という目的 よりもむしろ城郭の機能（戦闘要塞、威嚇、権力の象徵） を停止・凍結させた、つまり“城を使わない”という意 志を視覚的に表明するための儀礼的要素が強く作用した 結果ではないかとの見解を提示した。ここに「城割」に おける儀礼的要素について「縄張り研究」の立場から新 たな一事例が提示できたのではないかと考える。また、 肥前名護屋城の石垣の破却の目的については、破却形態 が儀礼的であることを根拠として、寺澤氏が幕府に対し 私戦の凍結の意を表明するために行ったと推察した。石 垣の破却の時期については、唐津築城時ではなく元和か 寛永である可能性を指摘したが、その何れであるかは現 段階では特定するまでには至らなかった。ただし、石垣 の破却の時期を寛永の「城割」とする場合に生じる問題 点の所在を提示した。

なお、以上の考察が正しいとするならば、肥前名護屋 城石垣に見られる崩壊した遺構の状態そのものが「城割」 の実態を示す事例として歷史的価值を持つものであると いえる。しかし現在、肥前名護屋城では崩壊した石垣の 
積み直し作業が進行中である。既に山里曲輪の外妌形虎 口および城内の櫓台の幾つかは積み直しが完了している 状態である。その際、崩壊していた石垣が、自然崩壊な のか、破却なのかを考古学的に特に検証した様子はない。 今後、他の崩壊部分の積み直しが進行するであろうと思 われるが、その際、考古学的検証が行われることを望み たい。また結果、破却であることが検証された場合、安 易な積み直しが控えられることを望みたい。本稿が今後 の積み直し計画に再考を与える契機となれば幸いである。 なお、本稿は平成六年度文部省科学研究費補助金（特 別研究員奖励費、人文）による研究成果の一部をまとめ たものである。

註

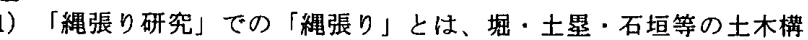
築物によって作り出される城部の“かたち”（堀・土畋・虎口の 形状 $\left(フ^{\circ} ラ\right.$ ラ 、曲輪の配置や形状等) をいう。

2）筆者のいう「縄張り図」とは、堀・土疁・石垣等の土木遗構を表 面観察し、それがどのように有機的に合わさって城郭の“かたち ”を構成しているのかを評価し、それを図面化したものである。 表面観察する地形に対して評価が入万点で、等高線による実測図 とは性格や目的が異なる。「縄張り図」の性格と有效性および等 高線による実測図との違いについては（文献 1) ・（文献 2）に 詳しく述べられているので参照されたい。

3）『別本吉川家譜』・『細川家記』・『松井家譄』(文献 3 に収録) 等の古記録においては、「城割」、「破却」、「城破」、「城刷 という語が同義語として使われている。

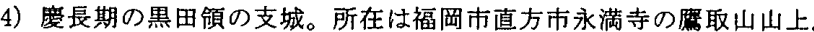
発把調查により「城割」による石垣の破却が確認されている（文 献 4)。

5）切石と完成された算木樌みによる高度な石垣の技法より慶長期の 寺澤領の支城と考えられる。所在は佐賀県蕨木町浪瀬の城山山上。

6）宮田逸民氏により播糜利神城石垣の城割が報告されている（文献 6）。氏の論考の主旨は、まず石垣の崩壊のメカニズムを考察し、 次に利神城・石垣山城の崩壊箇所において、出隅部分の石垣の脇 が大きく崩れているにも関わらず出隅部分の石垣ははらみながら も健在している状態を以て出隅部分の石垣は崩れにくいという前 提を導き、その上で周辺の石垣に異常が無く出隅部分の石垣のみ 崩れている場合を「城割」による破却と判定するものである。し かし、果たして出隅部分の石垣は周辺の石垣よりも必ずしも崩れ にくいといえるのかという疑問が残る。それは、マスタバ（古代 エジプトの墳基）をみた場合、むしろ䧉部分および天端部分が崩 壊しており、一般的に出隅部分は自然崩壊しやすいのではないか と思われるからである。また、利神城において腢石垣になってい る筒所は全て崩壊しているわけではなく、主郭部をはじめかなり の䉪所は健在しているが、主郭部に「城割」がないという状態に は少々疑問が残る。そのため宮田氏が認定された利神城等の石垣 の破却については、「城割」によるものなのか、自然崩畷なのか、 あるいは後世の石取りによるものなのかについて、まだ墥論が分 かれるところではないかと思われる。ただ、宮田氏の論考は、利 神城を中心に岩国城、下津井城等の石垣の崩壊を「縄張り研究」 の立場ら「城割」として初めて本格的に論じ、議論の必要性を提 示した点で先駆的な研究である。宮田氏によって提起された石垣 の破却にたいする問題に今後、特に重点的に取り組んで行く必要 を感じる。

7）外妌形虎口は祵線から「腕」を外側に張り出す形状のものをいう。 これについては千田嘉博氏の解釈による（文献 9 ）。

8）以下に举げる史料は吉村茂三郎編『松浦敾書』巻 1 , 巻 2 (文献 10，11）に収録されている。吉村氏の解題による上『唐津拾風土 記』の多くの部分が『松浦拾風土記』とほほ同一の内容であると している。そして『唐津拾風土記抄』は後者と内容の異なる部分 を選択抄録したとある。各史料は著者・成立年代に不明な点が多 く、相互関係は明らかでない。

9）（著）河東義剛、（成立）文化 4 年 (1807)、（写本）長崎県立図 書館・東大史料編箱所・内閣文庫、（活字）（文献10）収録
10）（著）不明、（成立）不明、（写本）国会図書館・内閣文庫・東 大史料編策所、（活字）（文献10）収録

11）（著）松浦大教、（成立）文化年間（1804～1818）（活字）（文献 10）収録

12）（著）不明、（成立）文化年間 $(1804 \sim 1818 ）$ （活字）（文献 11) 収制

13）（著）不明、（成立）文化年間、（写本）佐賀鍋島家、（活字） （文献10）収録

14）(著）不明、（成立）不明、（所蔵）佐賀県鎮西町広澤寺、（活 字）(文献12）収録、寺伝を縉編集したものである。なお、寺 澤氏は正保 4 年 (1647)に改易になっているので、文中の「享保二 年迄百二十年程然共」という記述は明かに誤りである。

15)この伝承は（文献12）に述べられているが、典抛があるのかある いは口承なのかについては記載がなくわからない。

16）『蜂須賀家記』（文献13）、『越登賀三州志』（文献13）、『肥 後宇士軍記』（文献14）、〔寛永15年〕卯月十三日「毛利秀就書 状」（文献15）、〔寞永15年〕「六月七日、松平伊豆守殿江之御 書」（文献16）等には、寛永の「城割」令の存在を伺わせる記述 がある。ただ、どの程度の破却を行ったのかについては詳しく記 されていない。【宽永15年】「六月七日、松平伊豆守殿江之御書 （文献16）によると、佐敷城（旧加藤領）の石垣は元和の「城割」 で崩されていたが、石の見えるところが少しあったので、この度 （䙾永15年）石をのけさせたとある。しかし、佐敷城には現在も 石垣がかなりしっかりと残っている简所があり（文献17）、実際 にどの程度の破却が行われたのかは、文献のみでは判断できない。 17)岩国城の「城割」に関しては、『別本吉川家䲕』「廣正公ヨリ御 本家へ差出サル、御書物」(文献 3 収録) と[䙾永15年了卯月十 三日「毛利秀就書状」（文献15）がありここれらから岩国城の石 垣は元和と寞永の二度の「城割」令によって破却されたことが推

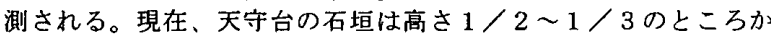
ら上が崩罗しており、1994 年の発掘調查によって「城割」の 状況が確認された。発掘を担当した山口県埋藏文化財センターの 豊島正行氏に伺った話によると、天守台部分の建物の破壤は元和 の「城割」、石垣の破却は寛永の「城割」によるものと判断でき るとのことである。その根拠を要約すると、天守台の裾には一層 の瓦の堆楮層や漆喰と思われる石灰層があり、その上に数十年分 に相当すると思われる二次堆䄼層を挟んで石材が堆䅢している状 況があり、これから、まず、天守が崩され、数十年空けてその上 から石垣が崩されたことが推定できるとのことである。つまり、 瓦と石灰の堆䅡層は最初の「城割」である元和の「城割」令によ るものと考えられ、その後の年月を経た石垣の崩填は䙾永の「城 割」と判断できるとのことである。ただ、今回発㨄された天守台 以外の筒所での石垣の崩壊については、まだその時期は判断はで きないとのことである。

18）『別本吉川家譜』「席正公ヨリ御本家へ差出サル、御書物」（女 献 3 収録）には「城ノヨモテノ方 7 取分 下ヨリモ城ヨリモ、ヨク御見合候へク候トアリ」とあり、吉川氏 が家臣に、とりわけ表の方の石垣を山下からも城からもよく見え るように崩すよう指示している。

19)本丸東側の虎口については、“腕(2)”怔疁線上り内側に入る形状 から内栎形との中間型とも解釈できるが、“腕(1)”の上うに畋線 から外に大きく振り出す形状とこれに連なる東出丸（仮称）の相 関から考えると、強い出整性を示寸外妌形々解釈することが妥当 であると考える。これについては、千田氏の解喽（文献 9 ) が参 考になる。

20）（作成）佐賀藩御境目方模写、（成立）天保 8 年 (1837)、

(所藏) 鍋島報佼会所有、佐賀県立図書館荿

21）（作成）佐賀藩、（成立）正保 4 年（1647）、（所蔵）鍋島報佼会 所有、佐賀県立図書館蔵

22）『別本吉川家譄』「廣正公ヨリ御本家一差出サル、御書物」（文 献 3 収録）によると、吉川氏は毛利辉元から岩国城の破却を命じ られた際、“毛利領は防長二カ国なので二城を残してもよいはず である。防州には岩国城しかないので残しても構わないはずであ る。そ机に先年より自分が岩国城に居城していることは家康公も 御存知のことだから幕府へ一旦、伺いを立てて頂けないか”と返 答している。しかし、洅元は「長府之城同前二卜被思召、御内意 共候哉、彌破却可仕之由、重悬御意付而、不能違背、城ワリ申侯 トアリ」と、強い態度で岩国城の破却を重礼て要求している。こ こには岩国城の「城割」に対する燐元の㮴極的な姿勢が窥わ机る。

23) 寬永 7 年の『寺澤侯寛永高帳 全』（松尾家所蔵、唐津市立近代 図書館にコピー製本有り)をみると、肥前名護屋城が位置する名 護屋村は寺澤氏の蔵入（直轄）地となっている。また、名護屋城 の規模・土木量が本城唐津城を淩ぐものであったことを考えても 大身家臣の持ち城ではなく寺澤氏の直轄であった可能性が高い。 
文献

1) 八巻孝夫：「中世城館研究への提言」（『地方史研究 202』、 地方史研究協議会、名著出版、1986.8)

2）千田嘉博：「中世城垶加近世城郭人一山城の縄張り研究加ら一」 （『月刊文化財 305』、第一法規出版、1989.2）

3)『大日本史料 12-21』、東京大学史料編篹所編、東京大学出版会、 1973. 10

4）『筑前鷹取城跡（IV) 』、直方市教育委員会、1990.3

5)『東北横断自動車道遺跡調查報告 15 木村館』、福島県教育委 員会・福岛県文化センター・日本道路公団、1992.12

6) 宫田逸民：「利神城の城割について」（『播磨利神城』、城郭视 話会、1993.8)

7)『根城一本丸の発㓰調査』、八戸市教育委員会、1993.3

8）「城を破る一降参の方法(2)」（『歷史を梳みなおす 15 城と合戦』、 朝日新閏社、1993.10)

9) 千田嘉博：「織豊系城郭の椿造一虎ロプランによる䋥張り編年の 試み」(『史林70-2』、京都大学文学部史学研究会、1987.3)

10）吉村茂三郎編：『松浦叢書第 2 卷』、松浦史談会、1938.1
11) 吉村茂三郎編：『松浦港書第 1 巻』、松浦史談会、1934.4

12）『名護屋城秘史』、名古屋宇太郎・名古屋経一著、名護屋城阯研 究會、 1930.7

13)加藤隆『幕藩体制と城郭』、近世日本城部研究所、1983.2

14）宇土市埋蔵文化財調查報告書第 1 集『宇土城跡（西岡台）』、宇 土市教育委員会、1977.

15）『岩国城と錦带橋史料』、岩国徵古館、1966.3

16）出水踥書『綿考輯録』第六巻【細川忠利公（下）]、出水神社、 汲古書院、1990.11

17)拙稿「近世初頭九州における支城の䋥張り構造一佐敷城（肥後加 藤領）における大名権力との相関一」（『日本建築学会大会学術 講演梗概集』（東海）、1994.3）

18）山口県埋蔵文化財調查報告第 173集『岩国城跡（天守）』、山口 県埋蔵女化財センター、岩国市・岩国市教育委員会、1995. 3

19）『特別史跡名護屋城跡並び陣跡 3 文禄・慶長の役城跡図集』、 佐贺県教育委員会、1985.

20）『松浦記集附録一』、（著）河東義剛、（成立）文化 4 年（1807）、 （写本）長崎県立图害館 